\title{
PERBEDAAN MOTIVASI KERJA ANTARA KARYAWAN KONTRAK DAN KARYAWAN TETAP PADA PT. BANK RAKYAT INDONESIA CABANG CIMAHI
}

\author{
Fajar purnama Arif \\ Fakultas Psikologi UIN Sunan Gunung Djati Bandung, Jl. A.H Nasution No. 105 Bandung \\ email:
}

\begin{abstract}
Abstrak
Dalam penelitian ini dilakukan studi komparasi terhadap motivasi kerja antara karyawan kontrak dan karyawan tetap yang bekerja di PT. Bank Rakyat Indonesia Cabang Cimahi. Sample sebanyak 40 karyawan mewakili teller dan customer service. Design penelitian menggunakan kuantitatif. Alat ukur yang digunakan adalah skala ukur MAI (Motivation Assesment Inventory) yang bersumber dari prototype motivasi kerja dari Denies C Kinlaw (1981). Hasil analisis data memperlihatkan bahwa probabilitas lebih besar daripada 0,5 yang artinya $\mathrm{H}_{\mathrm{o}}$ diterima dan $\mathrm{H}_{1}$ ditolak, sehingga dapat dikatakan terdapat perbedaan motivasi kerja antar karyawan kontrak dan karyawan tetap.
\end{abstract}

Kata Kunci : Motivasi Kerja, Kinerja karyawan tetap dan kontrak.

\section{Abstract}

This research used comparative study to compare motivation between contracted employee and permanent employee who work at PT Bank Rakyat Indonesia Cimahi branch. Sample are 40 employee represent teller and customer service division. Qualitative study is used with comparative analysis. Instrument used is Motivation Assesment Inventory from Denies C Kinlaw (1981. Data analysis result probalility more than 0,5 so that $H_{o}$ is accepted and $H_{1}$ is rejected. It is concluded that there is different work motivation between contracted employee and permanent employee.

Keywords : work motivation, performace of contracted and permanent employee

\section{PENDAHULUAN}

Manusia dalam sebuah organisasi memiliki peran sentral untuk menggerakkan roda perkembangan dan laju produktivitas organisasi. Mengingat peran yang cukup dominan, maka segala upaya yang dilakukan untuk menentukan sebuah sistem yang mengatur kinerja manusia agar lebih efektif dan efisien dalam organisasi akan terus dilakukan. Belum lagi meng- hadapi laju modernisasi dan perkembangan teknologi yang menuntut institusi organisasi untuk peka dan responsif terhadap tuntutan zaman.

Kualitas sumber daya manusia mempunyai pengaruh yang signifikan pada kemampuan dan kemajuan organisasi. Sumber daya manusia merupakan aset penting yang sangat berharga untuk menunjang keberhasilan organisasi. Oleh 
karena itu, agar sebuah organisasi atau perusahaan dapat lebih berkembang secara optimal, maka rekrutmen terhadap orangorang potensial bermotivasi tinggi untuk mengembangkan sumber daya manusia, menjadi pilihan strategis yang harus dilakukan pengelola organisasi. Manusia sebagai sumber daya potensial merupakan sumber kekuatan suatu organisasi, sebab manusialah yang menggerakkan organisasi. Begitu pula sebaliknya, menggerakkan organisasi berarti harus menggerakkan manusianya.

Produktivitas dan kinerja yang tinggi akan lebih terjamin, jika organisasi mempunyai cara yang tepat untuk menjaga produktivitas karyawan. Melalui pemeriksaan psikologis dalam rekrutmen dan seleksi, organisasi akan memperoleh karyawan potensial yang sesuai dengan tuntutan pekerjaan. Demikian pula halnya untuk evaluasi potensi dan promosi karyawan, dapat dilakukan pemeriksaan psikologi yang berkaitan dengan prestasi kerja sehingga manajemen dapat mengambil keputusan dan penanganan yang tepat dalam mengembangkan SDM organisasi atau perusahaan.

Fenomena yang sering mencuat ke permukaan adalah munculnya istilah karyawan kontrak. Karyawan kontrak dalam peraturan ketenagakerjaan di Indonesia memang diperbolehkan dan sudah diatur. Kontrak kerja bagi karyawan sejatinya diberlakukan kepada pekerjaanpekerjaan yang memiliki karekteristik tertentu. Hal tersebut sesuai dengan UU ketenagakerjaan No. 13 tahun 2003.

Perbedaan utama dari status karyawan kontrak dan tetap adalah dari status legalnya, jika karyawan tetap tidak memiliki jangka waktu, untuk karyawan kontrak memiliki jangka waktu. Hal ini juga dituangkan dalam perjanjian kerja karyawan, karyawan kontrak akan diberikan Perjanjian Kerja Waktu Tertentu (PKWT) yang artinya memiliki jangka waktu habisnya hubungan kerja, sedangkan karyawan tetap dituangkan dalam Perjanjian Kerja Waktu Tidak Tertentu (PKWTT). Mengenai gaji, fasilitas, kesejahteraan, cuti, dll. Karyawan kontrak dapat memiliki hak yang sama dengan karyawan tetap tergantung dari perjanjian kerja yang disepakati bersama. Oleh karenanya semua hak dan kewajiban masing-masing pihak harus dicantumkan dalam perjanjian kerja dan karyawan harus cermat serta jeli mempelajari perjanjian kerja yang dibuat oleh perusahaan.

Sebagaimana layaknya sebuah organisasi, salah satu fungsi strategis yang memegang peranan penting dalam perbankan adalah sumber daya manusianya. Mengingat peran karyawan bank yang cukup dominan terhadap tingkat resiko operasional bank maka kualitas dan lingkungan kerja bank harus terus ditingkatkan. Ketidakmampuan manajemen bank dalam mengelola sumber daya manusia dengan baik akan mengakibatkan tingkat resiko operasional yang berbahaya.

Adanya perbedaan status karyawan ini pun berpengaruh terhadap kinerja karyawan di BRI. Hal ini diketahui dari narasumber yang menjelaskan bahwa saat ini kinerja karyawan yang ada yaitu karyawan kontrak dan karyawan tetap menunjukan adanya perbedaan dalam kinerja. Hal ini dapat dilihat dari penilaian performance dan kinerja kerjanya selama 1 tahun. Kinerja yang tinggi dapat tercapai oleh karena kepercayaan (trust) timbal balik yang tinggi di antara anggota anggotanya. Artinya para anggota mempercayai integritas, karakteristik, dan kemampuan setiap anggota lain. Untuk mencapai kinerja yang tinggi memerlukan waktu lama untuk membangunnya, memerlukan kepercayaan, dan menuntut perhatian yang seksama dari pihak manajemen.

Performance is defined as the record of outcomes produced on a specified job function or activity during a specified time period. Performance on the job as a whole would be equal to the sum (or average) of 
performance on the critical or essential job functions. The functions have to do with the work which is performed and not with the characteristic of the person performing (Bennet, 1991).

Berdasarkan keterangan di atas dapat pula diartikan bahwa kinerja adalah sebagai seluruh hasil yang diproduksi pada fungsi pekerjaan atau aktivitas khusus selama periode khusus. Kinerja keseluruhan pada pekerjaan adalah sama dengan jumlah atau rata - rata kinerja pada fungsi pekerjaan yang penting. Fungsi yang berkaitan dengan pekerjaan tersebut akan dilakukan dan tidak dilakukan dengan karakteristik kinerja individu. Kinerja merupakan penampilan hasil kerja pegawai baik secara kuantitas maupun kualitas. Kinerja organisasi merupakan hasil interaksi yang kompleks dan agregasi kinerja sejumlah individu dalam organisasi. Untuk mengetahui faktor yang mempengaruhi (determinan) kinerja individu, perlu dilakukan pengkajian terhadap teori kinerja. Program-program pendidikan dan pelatihan, perbaikan kompensasi dan pemberian punishment, serta penetapan jenjang karier yang jelas pada sejumlah karyawan dapat digunakan untuk meningkatkan kualitas sumber daya manusia (Siagian, 1995:88). Menurut Keith Davis (dalam Anwar Prabu Mangkunegara, 2005:67) salah satu faktor yang paling menentukan produktivitas karyawan adalah motivasi kerja. Motivasi kerja adalah daya penggerak yang memotivasi semangat bekerja seseorang, yang mendorong seseorang untuk mengembangkan kreativitas dan menggerakkan semua kemampuan serta energi yang dimilikinya demi mencapai prestasi kerja yang maksimal. Faktor motivasi memiliki hubungan langsung dan kuat dengan kinerja individual karyawan. Faktor tersebut keberadaannya akan mempengaruhi motivasi kerja karyawan karena kedudukan dan hubunganya itu, maka sangatlah strategis jika pengembangan kinerja individual karyawan dimulai dari peningkatan motivasi kerja Apabila karyawan memiliki motivasi kerja yang tinggi, maka perusahaan akan berkembang dengan cepat, yang akhirnya akan menghasilkan kinerja dan pencapaian yang baik bagi perusahaan. $\mathrm{Di}$ sisi lain, bagaimana mungkin perkembangan akan perusahaan berjalan baik, kalau karyawannya bekerja tidak produktif, artinya karyawan tidak memiliki semangat kerja yang tinggi, tidak ulet dalam bekerja dan memiliki motivasi yang rendah.

Menurut Davis \& Newstorm (1985: 90). Seorang yang termotivasi dalam bekerja adalah seseorang yang melihat bahwa pekerjaannya membantu mencapai tujuan-tujuan pentingnya. Tujuan adalah sesuatu yang ingin dicapai yang berada di luar diri individu, yang ada kalanya diartikan dengan harapan untuk mendapat suatu penghargaan, suatu arah yang dikehendaki oleh motivasi. Dalam psikologi, tujuan seperti ini dikenal dengan istilah reward. Namun demikian, istilah reward lebih dikenal masyarakat sebagai suatu hal yang berhubungan dengan penghargaan keuangan, misalnya: kenaikan gaji, upah, honorarium, ataupun tunjangan. Padahal ada reward yang tidak bersifat keuangan misalnya: kenaikan pangkat, penghargaan atau bintang jasa. Jadi, tujuan adalah ujung dari lingkaran motivasi yang mengundang semua kegiatan untuk mencapainya.

Motivasi merupakan pendorong yang menyebabkan seseorang rela menggerakkan segala kemampuan, tenaga dan waktunya untuk menjalankan semua kegiatan yang telah menjadi tugas dan tanggung jawab nya agar kewajibannya terpenuhi serta sasaran dan tujuan yang ingin dicapai perusahaan terwujud. Manusia memiliki banyak motivasi dasar yang berperan penting dalam dunia kerja yaitu motivasi yang diberikan perusahaan dan motivasi yang ada dalam diri karyawan. Sedangkan imbalan yang non finansial lebih kepada situasi lingkungan 
kerja yang tercipta dengan baik dan fasilitas-fasilitas yang mendukung kegiatan karyawan di tempat bekerja sehingga karyawan merasa nyaman dan dapat bekerja dengan baik.

Dalam dunia kerja, motivasi menempati unsur terpenting yang harus dimiliki karyawan. Sebab motivasi merupakan kemampuan usaha yang dilakukan seseorang untuk meraih tujuan dan disertai dengan kemampuan individu untuk memuaskan kebutuhankebutuhannya. Pekerja atau karyawan yang memiiki motivasi kerja tinggi akan selalu mencoba melakukan yang terbaik, serta bersedia meluangkan waktu dan upaya ekstra untuk melakukan pekerjaannya. Sedangkan pekerja yang mempunyai motivasi rendah adalah pekerja yang seringkali tidak mau melakukan yang terbaik serta jarang meluangkan waktu dan upaya ekstra untuk melakukan pekerjaannya, ( Kinlaw $1981: 5$ ).

Motivasi karyawan dalam bekerja di suatu perusahaan (dalam hal ini bank) yang baik akan memberikan dampak positif, baik bagi diri individu maupun pihak bank. Sikap positif yang ditunjukkan karyawan terhadap perusahaan, merupakan cerminan motivasi pada diri karyawan tinggi. Pengelola bank, dalam konteks ini harus memberikan jalan terbaik, dengan cara lebih memperhatikan para karyawan agar mereka dapat bekerja secara efektif. Motivasi menjadi komponen yang sangat berperan dalam mewujudkan sumber daya manusia yang berkualitas. Karyawan memiliki motivasi yang tinggi akan mempunyai semangat, keinginan dan energi yang besar dalam diri individu untuk bekerja seoptimal mungkin. Motivasi karyawan yang tinggi akan membawa dampak positif bagi perusahaan dan meningkatkan daya saing para karyawan.

Berkaitan dengan motivasi yang sangat penting dalam operasi perusahaan, dewasa ini adanya persaingan antar perusahaan bank yang semakin meningkat, menuntut perusahaan untuk beroperasi secara efektif dan efisien. Salah satu kerugian yang dialami Bank BRI dalam hal rekrutmen adalah perusahaan seringkali menanggung pembayaran biaya pesangon yang cukup tinggi pada saat akan melaksanakan operasi perusahaan yang lebih efektif. Adanya kenyataan ini mendorong perubahan sistem rekrutmen sumber daya manusia PT. Bank Rakyat Indonesia (Persero). Salah satu alternatifnya yaitu mengadakan sistem kontrak karyawan. Di dalam sistem kontrak, pihak PT. Bank Rakyat Indonesia (Persero) memberikan syarat-syarat dalam penerimaan karyawan yang memiliki dedikasi tinggi dan berpengalaman (Warta BRI, 2002).

Pihak Bank menerapkan sistem kontrak terhadap beberapa karyawan di bagian-bagian tertentu. Salah satu sistem kayawan kontrak yang telah diterapkan di BRI adalah selama 1 (satu) tahun, jika karyawan tersebut memiliki dedikasi yang tinggi selama bekerja maka ada kemungkinan dapat diangkat menjadi karyawan tetap. Pihak Bank tidak akan memperpanjang kontraknya jika selama masa kontrak 1 (satu) tahun karyawan tersebut tidak bekerja dengan baik maka setelah kontraknya habis langsung dilakukan pemutusan kerja kepada yang bersangkutan.

Mengingat adanya pikiran dan perasaan penuh ketidakpastian, maka implikasi psikologisnya akan terlihat pada motivasi karyawan. Namun demikian, ketidakpastian masa depan juga bisa menambah semangat kerja atau motivasi kerja karyawan kontrak untuk semakin produktif dan mendapatkan penilaian lebih baik dari perusahaan. Hal ini karena produktivitas dan kinerja karyawan kontrak, merupakan penilaian utama diperpanjangnya masa kontrak mereka oleh perusahaan. Salah satu faktor yang harus dimiliki para karyawan adalah motivasi dalam bekerja, yang berfungsi 
untuk memacu semangat kerja dan prestasi kerja karyawan.

Lebih lanjut, disebutkan bahwa para karyawan yang bekerja di PT. Bank Rakyat Indonesia (Persero) dan terikat sistem kontrak ataupun outsourcing adalah karyawan pada bagian teller, unit pelayanan nasabah (customer service), satpam, pramubakti (cleaning service) dan supir adalah karyawan outsourching, karyawan di bagian teller dan unit pelayanan nasabah memiliki peluang lebih besar untuk diangkat menjadi karyawan tetap apabila pihak Bank merasa puas dan mempertimbangkan perpanjangan kontrak mereka atau mengangkat menjadi karyawan tetap.

Secara umum, pihak Bank menginginkan para karyawannya untuk berkarya pada perusahaan bersangkutan selama masa aktif kontraknya. Dengan kata lain pihak Bank tidak menginginkan terjadinya pemutusan kerja setelah masa kontraknya habis dengan berbagai alasan, karena pihak Bank harus kembali merekrut karyawan kontrak baru dan memerlukan waktu lebih lama untuk proses perekrutan tersebut.

Pembaharuan kontrak diadakan hanya pada karyawan kontrak yang dinilai mempunyai prestasi kerja yang tinggi. Hal ini berakibat tingginya motivasi karyawan kontrak dalam bekerja, karena mereka tidak menginginkan prestasi kerjanya dinilai rendah oleh perusahaan, sehingga berakibat terjadi pemutusan kontrak oleh pihak bank.

Berbeda dengan karyawan kontrak, secara umum karyawan tetap yang bekerja dalam sebuah perusahaan cenderung merasa lebih aman. Sebab kepastian masa depan kerja sangat ditentukan oleh sikap positif yang ditunjukkan selama bekerja, dan tidak dibatasi oleh waktu atau masa kontrak. Salah satu faktor yang akan membuat mereka termotivasi dalam bekerja adalah pencapaian jenjang karier atau jabatan dalam perusahaan tersebut serta reward yang berbeda pada setiap jabatan yang dipegang oleh setiap karyawan. Namun sebaliknya, jika sikap positif yang ditunjukkan karyawan tetap dalam bekerja sangat minim, maka motivasi karyawan tetap tersebut akibatnya menjadi sangat rendah. Adanya rasa aman menjadi karyawan tetap, tak jarang menjadikan karyawan yang bersangkutan terlena dan tidak terpacu dengan targettarget perusahaan ataupun target - target karyawan sendiri sehingga menyebabkan adanya jabatan yang terlampaui antara karyawan yang lebih lama masa kerjanya dengan karyawan yang baru bekerja. Kondisi ini menciptakan situasi tidak produktif dalam diri karyawan dan tentunya akan sangat berpengaruh terhadap pencapaian target dan produktivitas perusahaan. Suatu motivasi cenderung berkurang kekuatannya manakala kepuasan telah tercapai, terhalangnya pencapaian kepuasan, perbedaan kognisi dan frustrasi (Griffin 1990: 143).

Selain itu dalam perjalanan karier, karyawan selalu memerlukan pembinaan sistematik yang tidak dapat didekati dengan cara-cara mekanistik, tetapi juga dengan memperhitungkan faktor-faktor motivasional yang berupa pendekatanpendekatan yang bersifat psikologis. Salah satu hal yang sangat penting adalah kejelasan tangga karier, karena setiap orang yang bekerja pada suatu perusahaan ingin mencapai kemajuan dalam kariernya, baik dalam pangkat maupun jabatan. Kejelasan tangga karier dinilai sangat penting, sehingga karyawan harus memiliki pengetahuan yang jelas mengenai prosedur jenjang karier apa saja yang terbuka apabila memenuhi persyaratan yang ditetapkan oleh pihak Bank untuk masing-masing bagian yang terdapat di lingkungan kerjanya. Dalam meniti kariernya, seorang karyawan dinilai dari prestasi kerjanya dan bukan dari kriteriakriteria yang subyektif seperti nepotisme dan kriteria lain sejenisnya, tetapi lebih kepada pertimbangan kemampuan seorang karyawan memberikan kontribusinya 
untuk kepentingan perusahaan secara keseluruhan.

Hal ini sangat penting karena persepsi karyawan tentang adil dan tidaknya kriteria-kriteria itu sangat mempengaruhi motivasi kerjanya. Penilaian seseorang mengenai kejelasan tangga karier menjadi bagian yang sangat penting jika dihubungkan dengan pemuasan berbagai kebutuhan seseorang, baik yang bersifat primer, sekunder dan intelektual psikologis. Hal itu membuat seseorang akan mulai membiasakan dirinya untuk hidup, berpikir, dan bertindak sesuai dengan kemampuan yang dimilikinya.

Motivasi juga merupakan akibat dari interaksi seseorang dengan situasi tertentu yang dihadapinya. Oleh karena itu terdapat perbedaan kekuatan motivasi yang ditunjukkan oleh seseorang karyawan dalam menghadapi situasi tertentu dibandingkan dengan orang lain yang menghadapi situasi sama. Bahkan seseorang akan menunjukkan dorongan tertentu dalam menghadapi situasi yang berbeda dan dalam waktu yang berlainan pula (Siagian, 1995 : 77).

Di BRI fenomena tentang perbedaan status karyawan kontrak dan karyawan tetap memberikan permasalahan yang signifikan untuk karyawan yang bekerja misalnya karyawan kontrak yang telah bekerja bertahun - tahun akan mengalami nasib yang tidak menentukan karena tidak mendapat kesempatan langsung menjadi karyawan tetap hal ini akan berdampak terhadap ketidakjelasaan di masa depan dan terhambatnya peluang karir yang lebih maju selain itu penerimaan upah dan tunjangan lainpun tidak sebesar karyawan tetap hal ini jelas akan menjadi damapak masalah karena diantara ketidakpastian tersebut karaywan kontrak harus tetap bekerja di bawah tekanan sedangkan motivasinya untuk bekerja tidak di dukung dengan statusnya di perusahaan dan adanya perbedaan sikap perusahaan terhadap para karyawannya. Sedankan karyawan tetap akan merasa tenang dalam bekerja karena statusnya sebagai karyawan tetap sehingga membuat karyawan tersebut memiliki jaenjang karir yang jelas, upah dan tunjangan yang lebih besar deari karyawan kontrak.

Perbedaan situasi yang dihadapi jelas akan sangat berpengaruh terhadap motivasinya dalam bekerja. Karyawan kontrak yang menghadapi situasi diatas dapat diputuskan kontraknya jika prestasi kerjanya rendah, akan termotivasi meningkatkan prestasi kerjanya untuk mempertahankan kontraknya. Karyawan tetap yang menghadapi situasi tidak akan mengalami kenaikan jenjang karier jika prestasi kerjanya rendah, akan termotivasi meningkatkan prestasi kerjanya untuk mencapai kenaikan jenjang karier yang diinginkannya.

Adanya karyawan kontrak dan karyawan tetap dalam sebuah perusahaan menjadi sebuah fenomena yang menarik untuk dikaji. Terutama dari segi motivasinya. Hal ini membuat penulis tertarik untuk meneliti "Apakah terdapat perbedaan motivasi kerja antara karyawan kontrak dan karyawan tetap pada PT. Bank Rakyat Indonesia Cabang Cimahi ?"

Seperti yang telah dipaparkan sebelumnya, bahwa fenomena adanya penetapan status kepegawaian di lingkungan perbankan cukup memberikan persoalan pada karyawan terutama karyawan kontrak karena aktivitas kerja dalam organisasi selalu dibayangi perasaan ketidakpastian, khususnya menjelang kontrak berakhir, namun demikian ketidakpastian ini dapat pula menjadi semangat kerja dan pruduktivitas kerja untuk semakin produktif dan menambah penilain lebih dari perusahaan. Berbeda dengan karyawan kontrak karyawan tetap cenderung lebih merasa aman karena dalam bekerja tidak terikat oleh waktu ataupun masa kontrak namun adanya rasa aman sebagai karyawan tetap tak jarang membuat karyawan terlena dan kurang 
terpacu dengan target-target perusahaan. Kondisi ini membuat situasi tidak produktif dalam diri karyawan dan tentunya akan sangat berpengaruh terhadap pencapaian target dan produktifitas karyawan. Salah satu faktor yang akan membuat mereka termotivasi dalam bekerja adalah pencapaian jenjang karier atau jabatan serta reward yang akan diberikan dalam perusahaan .

Keadaan itu yang kemudian membuat peneliti merasa perlu mengangkat fenomena ini menjadi sebuah permasalahan. Peneliti berasumsi bahwa permasalahan motivasi kerja kerap muncul karena beragam faktor motivasi kerja. Baik itu yang bersifat internal maupun eksternal. Berdasarkan uraian di atas, maka perumusan masalah dalam penelitian ini adalah " apakah terdapat perbedaan motivasi kerja antara karyawan kontrak dengan karyawan tetap pada PT. Bank Rakyat Indonesia Cabang Cimahi ?

Tujuan penelitian ini adalah ingin memperoleh gambaran empirik mengenai perbedaan motivasi kerja antara karyawan kontrak dengan karyawan tetap di PT. Bank Rakyat Indonesia Cabang Cimahi.

\section{KEGUNAAN PENELITIAN}

Hasil penelitian ini dapat memberikan manfaat dan memperkaya wawasan dalam hal motivasi kerja dan diharapkan dapat dijadikan bahan pembanding bagi semua pihak yang membutuhkan informasi mengenai motivasi kerja.

\section{MANFAAT PRAKTIS}

Hasil penelitian ini diharapkan dapat digunakan sebagai bahan pertimbangan di dalam perencanaan, analisis dan promosi jabatan. Hasil penelitian ini diharapakan menjadi acuan bagi pihak manajemen atau pengelola di perusahaan terkait tentang hal-hal yang memotivasi karyawannya, sehingga mampu menjadi acuan dalam menetapkan atau membuat kebijakan.
Penelitian ini menggunakan pendekatan kuantitatif, yaitu suatu metode kuantifikasi atribut-atribut psikologis melalui suatu alat ukur yang dapat diinterpretasikan. Interpretasi ini dapat lebih objektif apabila alat ukur tersebut diperoleh berdasarkan prosedur yang sistematis serta memiliki validitas, reliabilitas serta objektivitas yang cukup tinggi. (Azwar. 2004: 1-2). Menurut Riduwan (2005: 6) data kuantitatif merupakan data yang berwujud angkaangka yang diperoleh dari pengukuran langsung atau dari data kualitatif yang sudah dirubah ke dalam data kuantitatif.

\section{VARIABEL PENELITIAN}

Variabel utama yang dikaji dalam penelitian ini adalah motivasi kerja. Secara konseptual, motivasi kerja merupakan suatu proses pengaturan pilihan-pilihan yang dibuat oleh individu terhadap berbagai bentuk aktivitas yang sifatnya sukarela ( Vroom 1964 dalam Milton, 1981: 62-73) ).

Secara operasional, Motivasi kerja dapat dilihat dari skor total skala motivasi kerja yang menggambarkan besarnya kekuatan motivasi kerja. Skor yang besar menentukan motivasi kerja yang tinggi, sedangkan skor yang rendah menunjukkan motivasi kerja yang rendah. Seorang individu akan melihat derajat antara kebutuhan - kebutuhan (match) dengan apa yang dilakukan untuk memuaskan kebutuhan tersebut. Seorang individu juga akan membandingkan reward yang diperolehnya dengan kerugian yang dialaminya (return). Yang terakhir adalah peftimbangan seorang individu untuk menentukan sampai sejauh mana lingkungan pekerjaan menguntungkannya (expectation)

\section{KARAKTERISTIK SUBJEK PENELI- TIAN}

Subjek penelitian adalah benda, hal atau orang tempat data untuk variabel penelitian melekat dan yang dipermasalah- 
kan (Arikunto, 2000: 116). Pada penelitian ini subjek yang akan diteliti adalah karyawan kontrak dan karyawan tetap PT. Bank Rakyat Indonesia.

Populasi adalah totalitas semua nilai dari hasil menghitung ataupun perkiraan mengenai karakteristik tertentu dari semua anggota kumpulan yang lengkap dan jelas yang ingin dipelajari sifat-sifatnya (Sudjana, 1996 : 6). Adapun subjek yang akan dijadikan sebagai populasi dalam penelitian ini adalah karyawan kontrak dan tetap pada bagian teller dan customer service yang berjumlah 136 dengan rincian sebagai berikut:

Tabel 3.1

Data Karyawan Pada Bagian TELLER dan CS

\begin{tabular}{cccc}
\hline JABATAN & $\begin{array}{c}\text { KARYAWA } \\
\text { N TETAP }\end{array}$ & $\begin{array}{c}\text { KARYAWAN } \\
\text { KONTRAK }\end{array}$ & JML \\
\hline TELLER & 41 & 22 & 63 \\
CUSTOMER & 2 & 71 & 73 \\
SERVICE & 43 & 93 & 136 \\
JUMLAH & & & \\
\hline
\end{tabular}

Pada penelitian ini diambil sampel dengan menggunakan tekhnik "Simple Random Sampling” yaitu teknik pengambilan data dengan cara acak terhadap semua anggota.

Dalam teknik ini semua anggota memiliki peluang yang sama untuk dijadikan sampel. Diambil 40 subjek (29\%) sebagai sampel dengan asumsi bahwa jumlah tersebut dianggap sudah mewakili populasi. Sesuai dengan Arikunto (2000: 120) bahwa jika peneliti memiliki subjek kurang dari 100, lebih baik diambil semua sehingga penelitiannya merupakan penelitian populasi. Selanjutnya jika jumlah subjeknya besar dapat diambil antara $10-15 \%$ atau $20-25 \%$ atau lebih.

\section{METODE PENGUMPULAN DATA}

Metode yang akan digunakan dalam penelitian ini adalah metode komparatif. Menurut Arikunto (2000: 66) penelitian komparasi adalah penelitian yang dimaksudkan untuk mengetahui ada tidaknya perbedaan antara dua hal.
Penelitian ini bertujuan untuk mengetahui perbandingan motivasi kerja antara karyawan kontrak dan karyawan tetap. Perbandingan ini diperoleh dengan membandingkan rata-rata serta simpangan baku dari skor total subjek serta skor dalam tiap pertimbangan seseorang yang mempengaruhi motivasi kerja. Kemudian untuk menguji ada tidaknya perbedaan, dilakukan uji hipotesis.

a. Melakukan pengujian statistik dengan menggunakan bantuan program SPSS (Stastistical Program for Social Science)

b. Menginterpretasi hasil analisis statistik dan membahas berdasarkan teori dan kerangka berpikir yang digunakan.

c. Merumuskan kesimpulan penelitian dengan mengajukan saran-saran yang ditujukan untuk perbaikan penelitian selanjutnya.

d. Menyusun, memperbaiki dan menyempurnakan laporan hasil penelitian

e. Menuliskan laporan penelitian dalam format laporan ilmiah sekaligus sebagai bahan pertanggungjawaban.

\section{HASIL PENELITIAN}

Hasil interpretasi skor pada skala MAI menunjukkan bahwa satu subjek berada pada kategori motivasi kerja tinggi dan dua subjek berada pada kategori motivasi kerja rendah dan tiga puluh subjek berada pada kategori motivasi kerja sedang ( lihat lampiran 2 ).

Untuk mengetahui ada tidaknya perbedaan motivasi kerja antara karyawan kontrak dan dan tetap secara umum maupun untuk tiap dimensinya, maka dilakukan pengujian data secara statistik dengan menggunakan uji Mann - Whitney. Adapun hasil pengolahan data tersebut adalah sebagai berikut:

\footnotetext{
$\mathrm{H}_{0}: \mu_{1}=\mu_{2} \quad$ Tidak terdapat perbedaan motivasi kerja antara karyawan tetap dan karyawan kontrak

$\mathrm{H}_{1}: \mu_{1}=\mu_{2} \mid \quad$ Terdapat perbedaan kerja antara karyawan tetap dan karyawan kontrak
} 
Komparasi perbedaan motivasi kerja karyawan kontrak dan karyawan tetap.

Tabel 4.1

Hasil Mann - whitney perbedaan motivasi kerja

\begin{tabular}{|c|c|c|c|}
\hline Variabel & Hasil Uji & $\begin{array}{c}\text { Kritera } \\
\text { Pengujian }\end{array}$ & Kesimpulan \\
\hline \multirow{6}{*}{$\begin{array}{l}\text { Perbedaan } \\
\text { motivasi } \\
\text { kerja } \\
\text { karawan } \\
\text { kontrak } \\
\text { dan tetap }\end{array}$} & Mann-Whitney $\mathrm{U}=$ & - Jika & $\mathrm{H}_{\mathrm{o}}$ diterima \\
\hline & Wilcoxon & as $>0.05$ & \\
\hline & $=388,500$ & maka $\mathrm{H}_{\mathrm{o}}$ & \\
\hline & $Z=-1,700$ & diterima & \\
\hline & $\begin{array}{l}\text { Asymp. Sig. } \\
\text { tailed })=, 089\end{array}$ & $\begin{array}{l}\text { - Jika } \\
\text { probabilit }\end{array}$ & \\
\hline & $\begin{array}{l}\text { Exact } \quad \text { Sig. } \quad[2 *(1- \\
\text { tailed } \\
\text { (a) }\end{array}$ & $\begin{array}{l}\text { as }<0,05 \\
\text { maka } H_{\circ} \\
\text { ditolak }\end{array}$ & \\
\hline
\end{tabular}

Derajat kepercayaan yang digunakan dalam pengujian ini adalah sebesar $95 \%$ karenanya diketahui harga $\alpha$ sebesar 0,05 . Berdasarkan hasil perhitungan yang telah diperoleh diketahui bahwa probabilitas hasil perhitungan spss yaitu 0,089 >0,05. Bila dibandingkan dengan kriteria uji yang dikemukakan yaitu tolak $\mathrm{H}_{\mathrm{o}}$ jika probabilitas < 0 , 05 hasil yang diperoleh ini memiliki arti bahwa $\mathrm{H}_{\mathrm{o}}$ diterima dan $\mathrm{H}_{1}$ ditolak, sehingga dapat dikatakan bahwa tidak terdapat perbedaan motivasi kerja antara karyawan kontrak dan karyawan tetap.

Sebagaimana telah disebutkan pada pembahasan latar belakang masalah, peneliti hendak mengetahui perbedaan motivasi kerja antara karyawan kontrak dan karyawan tetap. Berdasarkan hasil analisis data, seperti yang dapat dilihat dalam tabel 4.1 diketahui bahwa tidak terdapat perbedaan motivasi kerja antara karyawan kontrak dan tetap pada PT. Bank Rakyat Indonesia Cabang Cimahi. Hal ini ditunjukkan oleh probablitas nilai hasil hitung yaitu nilai probabilitas nya lebih besar dari pada 0,05 .

Pada perhitungan pada motivasi kerja pada karyawan kontrak dan tetap menunjukan bahwa $\mathrm{H}_{\mathrm{o}}$ diterima pada taraf signifikan $\alpha=0.05$ berarti tidak terdapat pebedaan motivasi kerja antara karyawan kontrak baik aspek match, return maupun expectation, dengan motivasi kerja antara karyawan kontrak dan tetap di PT. Bank
Rakyat Indonesia Cabang Cimahi menunjukan adanya tampilan motivasi kerja positif seperti yang di tunjukkan pada lampiran 2 bahwa motivasi kerja karyawan menunjukan tingkat motivasi yang cukup positif.

Selain berdasarkan dari hasil uji statistik diatas, peneliti berasumsi bahwa tidak adanya perbedaan motivasi kerja antara karyawan kontrak dan karyawan tetap, terdapat beberapa faktor yang membuat karyawan kontrak dan karyawan tetap memiliki motivasi kerja yang sama diantaranya hal ini bias terjadi karena faktor perusahaan yang mampu memelihara situasi kerja karyawan dan lingkungan kerja sehingga para karyawan memiliki karyawan kerja yang baik, selain itu hal ini bisa disebabkan karena jumlah partisipan yang kurang sehingga mempengaruhi jumlah hasil para perhitungan atau bisa saja partisapan dalam mengerjakan soal yang diberikan tidak bersunguh - sunguh, selain faktor internal tersebut peneliti juga berasumsi faktor eksternal juga berpengaruh, antara lain alat ukur yang kurang cocok digunakan di perusahaan ini, karena alat ukur ini tidak sesuai dengan lingkungan kerja atau bahkan sudak out off date. Sehingga alat ukur ini harus diperbaharui. Tetapi diantara faktor-faktor diatas ada pula faktor pendukung lain dimana menurut Hezberg ( dalam Milton 1984)menyebutkan bahwa karyawan yang statusnya sementara dapat memiliki motivasi yang tinggi disebabkan karena statusnya yang tidak aman, sehingga karyawan tersebut memiliki motivasi kerja yang tinggi untuk mempertahankan posisinya atau dipromosikan menjadi karyawan yang tetap, tetapi karyawan tetap dengan statusnya yang telah aman bisa saja memiliki motivasi yang rendah karena statusnya yang bisa melindunginya, sehingga manakala kepuasan kerja telah tercapai faktor-faktor motivasi kerjanya menurun. 


\section{PEMBAHASAN}

Motivasi kerja merupakan suatu upaya (effort) yang dikeluarkan seseorang dalam bekerja, karyawan yang memiliki motivasi kerja yang tinggi akan selalu mencoba melakukan yang terbaik serta bersedia meluangkan waktu untuk melakukan pekerjaannya. Karyawan akan menjadi termotivasi bila dia bahwa pekerjaannya berhubungan dengan suatu yang penting bagi dirirnya (Kinlaw, 1981). Banyak hal yang dapat mempengaruhi motivasi seseorang didalam menghadapi pekerjaanya, diantaranya yang terpenting adalah masalah kebutuhan yang ada dalam diri masing - masing individu. Hal ini dimungkinkan bahwa sesorang bekerja adalah didorong untuk memenuhi berbagai kebutuhan dalam dirinya. Upaya pemenuhan kebutuhan yang merupakan tujuan seseorang melakukan pekerjaan ini sangatlah penting dalam memelihara motivasi individu dalam bekerja.

Motivasi kerja yang dimiliki setiap karyawan dalam menjalani pekerjaannya, merupakan interaksi antara karakteristik internalnya yang berbeda-beda, dengan tugas atau pekerjaan dan lingkungan pekerjaannya yang sama. Namun demikian, dalam menghayati tugas dan lingkungan pekerjaan yang sama ini setiap karyawan memperlihatkan respon yang berbeda-beda. Perbedaan itu tidak hanya karena perbedaan dari latar belakang yang sifatnya individual seperti: kebutuhan, minat, kemampuan, latar belakang kehidupan masa lalu, kepribadian dan keterampilan, tetapi juga karena perbedaan persepsi yang dimiliki tiap karyawan dalam menyikapi pekerjaan dan lingkungan kerjanya.

Motivasi kerja selain ditentukan oleh karakteristik internal juga ternyata ikut ditentukan oleh karakteristik eksternal, misalnya suasana yang tercipta di lingkungan kerja atau yang dikenal dengan istilah iklim kerja. Munculnya ketergugahan motivasi individu merupakan efek langsung dari iklim kerja. Hal tersebut merupakan hasil dari beberapa kondisi psikologis tertentu yang merupakan predisposisi individu untuk bertingkah laku dengan cara tertentu. Kesehatan fisik dan psikologis dapat dipengaruhi oleh keadaan iklim kerja yang dirasakan oleh individu. Iklim kerja yang sesuai dengan yang diharapkan individu akan menimbulkan motivasi kerja yang lebih baik. yakni dorongan yang berasal dari luar pekerjaan yang sedang dilakukan. Misalnya : bekerja karena upah atau gaji yang tinggi mempertahankan kedudukan yang baik, merasa mulia karena pengabdian dan sebagainya.

Selain faktor internal dan eksternal yang telah disebutkan di atas ada beberapa variable yang dapat mempengaruhi motivasi kerja karyawan pada saat bekerja, hezberg mengungkapkan bahwa variabel variabel ini dapat mempengaruhi motivasi kerja karyawan, apabila variabel ini di sikapi positif maka pengaruh terhadap motivasinya pun akan positif dimana karyawan akan memiliki motivasi kerja yang tinggi yang badak akhirnya akan berdampak pada kinerja dan produktifitas yang tinggi namun sebaliknya apabila variabel ini disikapi dengan negative maka motivasi kerja karyawan pun akan rendah sehingga akan berdampak terhadap kurangnya kinerja dan produktifitas, beberapa variabel ini yaitu :

a. Upah adalah pembayaran tetap secara bulanan atau mingguan yang diberikan pada setiap karyawan. Upah dibedakan menjadi 2 yaitu:

1. Upah berdasar waktu

a) upah (wages) yaitu upah yang dibayarkan kepada buruh kasar atau karyawan berdasarkan jam atau harian.

b) Gaji (salary) yaitu upah yang dibayarkan kepada manajer, karyawan kesekretariatan dan administratif berdasarkan periode waktu mingguan atau bulanan.

2. Upah borongan, yang mengaitkan langsung dengan jumlah produksi 
yang dihasilkan karyawan. (Dessler, 1986:350)

Pada PT. Bank Rakyat Indonesi gaji (salary) dibayarkan kepada karyawan kontrak dan karyawan tetap berdasarkan periode bulanan hanya saja akan berbeda pada besaran gaji yang diterima antara karyawan kontrak dan karyawan tetap mengingat adanya perbedaan status dimana karyawan kontrak masih pada tahap percobaan.

b. Situasi Kerja adalah keadaan yang mempengaruhi kegiatan perusahaan. Kondisi kerja yang lain mendorong semangat kerja karyawan seperti ketenangan, keamanan dan keselamatan kerja.

Perusahaan selalu berusaha membuat situasi kerja yang kondusif terhadap para karyawannya baik karyawan kontrak maupun karyawan tetap dengan cara berusaha membuat sistem yang baik dari hari kehari agar terciptanya ketenangan keamanan dan keselamatan kerja, misalnya pada karyawan kontrak bagaimana perusahaan membuat para karyawan kontrak tetap memiliki motivasi yang tinggi walaupun situasi kerjanya tidak memiliki ketenangan kerja karena masih berstatus karyawan kontrak begitu pun pada karyawan tetap bagaimana perusahaan menjamin keamanan kerja pada karyawan tetap karena mereka merupakan salah satu aset terpenting dalam menjalankan perusahan hal inilah mendasari pihak bank selalu berusaha menciptakan situasi kerja yang kondusif walaupun dengan tuntuan dan beban kerja yang berat dari perusahaan.

c. Fasilitas Kerja adalah sarana yang disediakan perusahaan untuk memperlancar jalannya aktivitas, dengan berbagai bentuk seperti:
1. kondisi tempat kerja (AC, penerangan, suhu, ukuran ruang)
2. teknologi yang digunakan (komputer

dan sebagainya)

3. sarana pendukung lainnya (kantin, loker, musholla, smoking area, rest room)

Untuk memperlancar aktivitas pekerjaan dan menjaga motivasi kerja karyawannya, perusahaan berupaya memberikan fasilitas fasilitas yang dapat membantu lancarnya sebuah pekerjaan seperti kondisi tempat kerja yang nyaman, teknologi yang dapat menunjang pekerjaan dan beberapa fasilitas lainnya seperti inpentaris kendaran bermotor, kesehatan dan pendidikan hanya saja pada karyawan kontrak beberapa fasilitas pekerjaan belum mereka gunakan mengingat mereka masih berstatus karyawan kontrak.

d. Sikap manajemen terhadap karyawan

Pada dasamya setiap karyawan ingin diberlakukan secara adil. Para karyawan dalam setiap perusahaan ingin agar suara mereka juga ikut didengar jika perusahaan melakukan hal yang tidak berkenan dengan harapan mereka. Manajemen perlu menerapkan pendekatan yang proaktif dengan cara:

1) merancang pekerjaan-pekerjaan yang memuaskan karyawan

2) menetapkan standar-standar prestasi kerja yang adil

3) melatih karyawan sehingga memungkinkan mereka untuk mencapai tingkat prestasi yang diharapkan. (Handoko, 1997:217)

Di perusahaan ini hubungan manajamen dengan karyawan bersifat vertical dimana hubungan antara manajemen dan para karyawan kontrak dan tetap yaitu berupa hubungan atasan dan bawahan dan perbadaan karyawan kontrak dan tetap ada pada status, fasilitas dan kebijakan yang diberikan tetapi level posisi mereka sama.

e. Sikap antar teman sejawat

Manusia sebagai makhluk sosial membutuhkan persahabatan untuk itu akan 
melakukan hubungan dengan temantemannya. Seorang karyawan sering berhubungan dengan karyawan lainnya hanya karena terdorong perasaan ingin mempunyai teman. (Ranupandojo, 1990:187)

Selain menciptkan hubungan yang harmonis antara rekan kerja, di perusahaan ini tidak menutup kemungkinan terjadinya persaingan antara rekan kerja hal ini mengingat tidak semua karyawan baik kontrak maupun tetap yang mendapat promosi dan reward karena mereka yang mendaptakan promosi dan reward adalah karayawan yang benar - benar berpretasi di antara karyawan lainnya sehingga tidak menutup kemungkinan adanya persaingan untuk menunjukan prestasi yang baik.

f. Kebutuhan berprestasi

Setiap perusahaan hendaknya memberikan kesempatan kepada para karyawannya. Karyawan yang berprestasi diberikan penghargaan yang sesuai. Penghargaan itu dapat berupa pengakuan yang kemudian disertai pujian, hadiah, kenaikan gaji, kenaikan posisi, perpindahan dan sebagainya.

Karyawan kontrak yang berprestasi akan mengharapkan reward yang sesuai dari perusahaan, harapan akan kenaikan gaji dan kenaikan posisi adalah reward yang paling diharapakan karena dengan kenaikan gaji dan kenakan posisi menjadi karyawan tetap akan mebuat karyawan kontrak merasa aman dalam bekerja sehingga mereka bias fokus bekerja mengejar pretasi tertinggi yang hendak diraih begitupun dengan karyawan tetap reward akan kenaikan gaji, kenaikan posisi dan bonus atas prestasi yang telah dicapainya akan membuat karyawan tetap semakin termotivasi dalam bekerja

\section{g. Promosi}

Sistem untuk mempromosikan karyawan biasa disebut sistem promosi tertutup dan terbuka. "Sistem promosi tertutup adalah sistem dimana manager seringkali secara informal memutuskan karyawan mana yang dipertimbangkan mendapat promosi." (Griffin, 1998:230)

Keputusan biasanya dibuat secara informal (dan seringkali subyektif dan cenderung bergantung pada rekomendasi penyelia yang terdekat). Sistem ini sangat populer khususnya di perusahaan kecil karena meminimalkan waktu, energi dan biaya pembuatan keputusan.

"Sistem promosi terbuka adalah sistem dengan karyawan melamar, diuji dan diwawancara sehubungan dengan peketjaan yang tersedia yang diumumkan secara terbuka." (Griffin, 1998:231)

Sistem ini memungkinkan pars karyawan mempunyai lebih banyak andil dalam jalur karir meitka dan sifat demokratis clan sistem terbuka ini dapat memberikan sumbangan pada moral karyawan yang lebih tinggi.

Promosi diberikan oleh perusahaan bagi karyawan kontrak dan tetap yang berprestasi, bagi karyawan tetap hal ini merupakan kesempatan untuk lebih mengembangkan karir dan bagi karyawan kontrak hal ini merupaka kesempatan untuk menjadi karyawan tetap serta mengembangkan karir dan mewujudkan harapan - harapan akan pekerjaan.

h. Kebutuhan untuk meningkatkan kemampuan

Orang masih merasa dirinya kurang puas, ingin berkembang lagi dan meningkatkan kemampuannya walaupun kebutuhan lainnya telah terpenuhi. Kurt Goldstein (Maslow, 1984:52) mengatakan bahwa keinginan orang akan perwujudan diri yakni kecenderungan untuk mewujudkan dirinya sebagai apa yang ada dalam kemampuannya. Kecenderungan ini dapat diungkapkan sebagai keinginan untuk makin lama makin istimewa, untuk menjadi apa saja menurut kemampuannya

Untuk itu perlu adanya pelatihan dan pengembangan lebih lanjut untuk melakukan tugas-tugasnya secara sukses. " Pelatihan adalah suatu kegiatan dari 
perusahaan yang bermaksud untuk dapat memperbaiki dan memperkembangkan sikap, tingkah laku, keterampilan dan pengetahuan dari pain karyawan sesuai dengan keinginan dari pemsahaan yang bersangkutan." (Nitisemito, 1996:86).

perusahaan ini sadar betul akan pentingnya peningkatan kemampuan karyawannya, untuk itu perusahaan selalu mengadakan pelatihan guna meningkatkan kemampuan karyawan dalam bekerja, pelatihan biasanya diberikan kepada karyawan baru dan karyawan yang dipromosikan atau dipindahkan untuk menduduki jabatan dan tanggung jawab baru yang dipegang karyawan.

\section{i. Insentif}

Insentif merupakan suatu sistem pemberian balas jasa yang berupa financial. Insentif merupakan suatu pendekatan kompensasi yang menghargai atau memberikan imbalan kepada karyawan atas hasil tertentu yang dicapainya. " (Werther, 1989:363)

Faktor dan varibel - varibel tersebut lah yang menjadi arah menentukan suatu motivasi kerja karyawan apakah karyawan tesebut memiliki motivasi kerja yang tinggi atau sebaliknya, demikian pula dengan karyawan kontrak beberapa faktor dan variabel tersebut dapat mempengaruhi suatu motivasi kerja karyawan kontrak.

Begitu pula dengan karyawan yang berstatus sebagai karyawan tetap faktor faktor dan variabel yang di sebutkan di atas dapat membantu karyawan tetap untuk memiliki motivasi yang tinggi apabila karyawan tersebut memandang hal - hal tersebut secara postif selanjutnya apabila karyawan tersebut memandang faktor dan varibel tersebut secara negative maka karyawan tesebut akan menampilkan motivasi kerja yang rendah beberpa hal di antaranya ialah :

\section{Pembayaran, seperti gaji dan upah}

Semua karyawan yang berstatus kontrak, menginginkan sistem upah dan kebijakan promosi yang dipersepsikan secara adil, tidak meragukan dan segaris dengan pengharapannya. Apabila gaji yang didasarkan pada tuntutan pekerjaan, tingkat keterampilan individu dan standar pengupahan komunitas, maka kemungkinan besar akan memotivasi kerja. Namun seringkali yang terjadi harapan tidak sesuai dengan kenyataan, apalagi pada mereka yang berstatus karyawan kontrak dimana pembayaran yang diberikan tidak termasuk di dalamnya tunjangan-tunjangan, sehingga membuat mereka kadang kurang termotivasi berbeda dengan karyawan kontrak, karyawan tetap mendapatkan hak gaji dan tunjungan yang lebih besar dari pada karyawan kontrak hal ini dikarenakan statusnya yang permanen sehingga perusahaan tidak mau mengambil resiko apabila para laryawan yang telah di ankat menjadi karyawan tetap menampilkan motivasi kerja dan kinerja yang rendah apabila haknya disamakan dengan karyawan kontrak tetapi apabila karyawan tetap tersebut menanggapi hal ini dengan negative dan terlena ataupun merasa puas dengan hal ini tidak memungkinkan karyawan tersebut menampilkan motivasi dan kinerja yang rendah

\section{Pekerjaan itu sendiri}

Kebanyakan karyawan cenderung lebih menyukai pekerjaan-pekerjaan yang memberi kesempatan mereka untuk dapat mengunakan kemampuan dan keterampilannya, kebebasan dan umpan balik berupa pernyataan tentang betapa baik mereka bekerja. Karakteristik seperti ini membuat pekerjaan akan terasa jauh lebih menantang. Pekerjaan yang kurang menantang, akan lebih cepat menimbulkan perasaan jenuh dan bosan. Tetapi pekerjaan yang sangat susah dilakukan dan terlalu menantang justru akan menimbulkan perasaan gagal dan frustasi. 
Apabila karyawan kontrak dan tetap menanggapi hal ini secara positif maka mereka akan semakin termotivasi dalam bekerja apabila mereka mendapakan pekerjaan yang memberikan kesempatan untuk menggunakan kemampuan dan keterampilan yang mereka miliki, hal ini kan membuat karyawan semakin bergairah dalam bekerja

3. Rekan kerja

Bagi kebanyakan karyawan, bekerja juga menciptakan suatu kesempatan untuk berinteraksi dengan sesama rekan lain dan melebarkan lingkungan sosial. Bekerja juga berarti pemenuhan kebutuhan manusia akan interaksi sosial dengan sesama. Sehingga tidaklah mengejutkan apabila lingkungan sosial di tempat kerja sangat kondusif, maka akan tercipta motivasi kerja yang tinggi tetapi tidak menutup kemungkinan akan terjadinya persaingan kerja diantara karyawan hal ini dimaksudkan karena pihak perusahaan akan memberikan rewar, promosi dan fasilitas lebih dari perusahaan bagi karyawan yang paling berprestasi dari karyawan lainnya, hal ini akan berakibat pada motivasi kerja apabila sikap karyawan terhadap situasi ini positif maka karyawan akan semakin termotivasi tetapi apabila sikap terhadap situasi ini negative maka tidak menunup kemungkinan motivasinya menurun.

\section{Promosi}

Promosi terjadi pada saat seorang karyawan tetap berpindah ke posisi yang lebih tinggi di organisasi tersebut, termasuk bertambahnya tingginya tanggung jawab dan jenjang organisasionalnya. Hal ini yang diinginkan para karyawan kontrak, termasuk peningkatan status mereka menjadi karyawan permanen. Pada saat dipromosikan, umumnya karyawan menghadapai tuntutan peningkatan kemampuan dan keahlian serta tanggung jawab. Sebagian besar karyawan sangat menantikan promosi dan merasa sangat positif ketika mendapatkannya. Promosi juga merupakan suatu sarana bagi organisasi untuk mendayagunakan kemampuan dan juga keahlian karyawannya setinggi mungkin.

\section{Supervisi}

Supervisi mempunyai peran yang sangat penting bagi manajemen dan para karyawan, hal ini dikarenakan supervisi berhubungan dengan karyawan secara langsung dan dapat mempengaruhi mereka dalam melakukan pekerjaannya. Pada umumnya karyawan lebih menyukai apabila mempunyai supervisi yang adil, terbuka dan mau berinteraksi dengan karyawan. Dengan supervisi yang sesuai dengan kriteria kebanyakan karyawan, maka peluang untuk menciptakan kepuasan kerja akan lebih tinggi.

Akhirnya, meskipun secara statistik proporsi jumlah karyawan kontrak dan karyawan tetap memiliki tingkat moivasi kerja tinggi, sedang dan rendah hampir sama, tetapi dimungkinkan mereka menampilkan motivasi yang berbeda. Hal ini dikarenakan karyawan kontrak tidak ingin setelah kontraknya selesai maka tidak ada pengangkatan statusnya menjadi karyawan tetap sebaliknya karyawan tetap tentu berharap akan dapat dipromosi ke jenjang karier yang lebih tinggi., Disamping itu, meskipun karyawan kontrak dan tetap hampir sama, tetapi peneliti menduga bahwa pendorong munculnya motivasi kerja diantara keduanya tetap berbeda. Hal ini memungkinkan karena faktor, variabel dan situasi kerja yang dihadapi pun berbeda.

\section{SIMPULAN}

Berdasarkan hasil analisis dan pembahasan tentang perbedaan motivasi kerja antara karyawan kontrak dan karyawan tetap pada PT. Bank Rakyat 
Indonesia Cabang Cimahi dapat ditarik simpulan sebagai berikut:

1. Tidak terdapat perbedaan motivasi kerja diantara karyawan kontrak dan karyawan tetap pada PT. Bank Rakyat Indonesia Cabang Cimahi. Hal ini memiliki arti karyawan kontrak dan tetap di perusahaan memiliki proporsi jumlah yang sama atau hampir sama dalam level motivasi kerja

2. Tidak adanya perbedaan motivasi kerja antara karyawan kontrak dan karyawan tetap menunjukan bahwa karyawan kontrak dan tetap memberikan kontribusi yang sama terhadap perusahaan karena memiliki motivasi kerja pada level yang sama.

\section{SARAN}

Berdasarkan hasil penelitian yang telah dilakukan, ada beberapa hal yang ingin peneliti ajukan kepada berbagai pihak, yaitu sebagai berikut:

1. Saran untuk Perusahaan

Motivasi kerja yang dibawa setiap individu akan berinteraksi dengan berbagai hal, terutama lingkungan yang ia temui. Perusahaan, dalam hal ini sebagai lingkungan yang ditemui oleh karyawan, harus mampu menciptakan situasi dan kondisi kerja yang memberi kenyamanan dan dukungan bagi karyawan untuk memunculkan kinerja optimalnya.

2. Saran untuk Karyawan

Motivasi kerja sifatnya individual, namun idealnya ia berasal dari dalam diri individu. Potensi ini nampaknya akan lebih kuat dalam membentuk hasil berupa kinerja yang optimal, sehingga harapan peneliti, setiap orang dapat memunculkan dan memelihara motivasi yang bersumber dari dalam dirinya.

3. Saran untuk Penelitian Selanjutnya
a. Hasil akhir penelitian ini memperlihatkan bahwa ada kontribusi variabel dan faktor yang berpengaruh terhadap munculnya motivasi kerja karyawan kontrak dan

tetap, sehingga peneliti berharap penelitian ini ditindaklanjuti untuk mengetahui variabel dan faktor tersebut.

b. Penelitian ini dilakukan dengan sampel yang berjumlah sedikit, sehingga peneliti berharap penelitian ini dapat dilakukan dalam populasi yang lebih besar guna melihat keakuratan data dan fakta.

c. Peneliti menilai masih banyak kekurangan yang dilakukan karena keterbatasan diri dan kemampuan, sehingga saran dan kritik atas proses dan hasil penelitian ini sangat diperlukan untuk evaluasi dan koreksi penelitian di masa yang akan datang.

\section{DAFTAR PUSTAKA}

A.A. Anwar Prabu Mangkunegara. 2001, Manajemen sumber daya manusia perusahaan, Bandung : Remaja Rosdakarya

Arep, I. dan Hendri T. (2003). Manajemen Motivasi. Jakarta: PT Grasindo.

Arikunto, S. (2000). Manajemen Penelitian. Jakarta: Rineka Cipta.

Atkinson, R.L. et, al. ( 2002 ). Introductions to Psychology $11^{\text {th }}$ edition (edisi terjemah: Pengantar Psikologi). Batam: Interaksara

Barbour dan Kitzinger. (2001). Developing Focus Group Research: Politics, theory and Practice., Reprinted Edition. London: SAGE

Bennett, R. (1981). Managing Personnel and Performance: An Alternative Approach. London: Business Books Ltd.

Chaplin. J. P. (2005). Kamus Lengkap Psikologi. Jakarta: Rajawali Press

Cokroaminoto. (2009). Awalnya Adalah Motivasi Kerja. Available At. http://berawal.wordpress.com

Davis, N. (1985). Perilaku dalam organisasi (Human Behavior at 
work: organizational behavior), edisi ketujuh. Erlangga: Jakarta.

Elliot, A.J. dan Dweck, C.S., (2005). Handbook Of Competence And Motivation. New York: The Guilford Press.

Encyclopedia, Wikipedia. Available at http://en.wikipedia.org/wiki

Friedenberg, Lisa. 1995. Psychological Testing Design, Analysis, and Use. Massachusetts: Allyn \& Bacon.

Guillford. J.P. 1959. Fundamental Statistic in Psychology and Education. New York: Mc Graw Hill Book Company.

Hasan, iqbal. ( 2008 ). Pokok - pokok materi statistic 2. Jakarta : Bumi Aksara.

Kinlaw, D.C. (1981). MAI: an analysis of motives to work. Virginia: Commonwealth Training Association Inc.

Lia Oktaviani, " Hubungan antara Motivasi Kerja dengan Hasil Kerja Karyawan Financial Advisor Bank Assurance DEPT pada PT. Asuransi AIG LIPPO LIFE BANDUNG" Skripsi Psikologi, ( Bandung: Perpustakaan UNISBA,2003)h. 35. t.d
Peorwandari, E.K. ( 2001 ). Pendekatan Dalam Penelitian psikologi. Jakarta: LPSP3 Fakultas Psikologi UI

Prithchad, R.D ( 2008 ), Work Motivation, Past, Present and Future. Florida : Taylor \& Francis Group, LLC

Santoso, Singgih ( 2002 ), SPSS Versi 10. Jakarta : Gramedia

Siagian, Sondang P. 1995, Manajemen sumberdaya manusia, Jakarta : Bumi Aksara

Siegel, Sidney. 1994. Nonparametric Statistics for the Behavioral Science (edisi terjemah). Jakarta: PT Gramedia

Steers, Porter. 1979. Motivation and work behavior, 2nd edition. Mc-Graw Hill: Singapore

Sudjana. 1996. Metoda Statistika edisi keenam. Bandung: Tarsito.

Thomas, K.W. ( 2009 ), Intrinsik Motivation At Work, California : Berret - Koehler Publisher, Inc.

( 2003 ). Undang-Undang Republik Indonesia Nomor 13 Tahun 2003 Tentang ketenagakerjaan karyawan kontrak, Jakarta: Panca Usaha

Warta BRI 2002: Bank Rakyat Indonesia, Jakarta 